\title{
Customer Satisfaction of the Product "ACME ERP”
}

\author{
K.Poovarasan, Fabiyola Kavitha, A.Kamal
}

\begin{abstract}
Today, shopper reliability has transformed into the key for association accomplishment and survival in overall test. In any case, various assessments on customer lead exhibit that delightful existing customers is easier than attracting new customers. Satisfying the customer is definitely not a basic technique and various assessments show it is multidimensional while the creating of online trades and online PC organizations hugy influences customer wants and dependability. So to speak, the customers become increasingly savvy and all the all the more mentioning.
\end{abstract}

Keywords : E-Learning Companies, Customer Satisfaction Level

\section{INTRODUCTION}

As of late, numerous online instruments (sites) have been created to contrast items or administrations and contenders' numerous organizations utilize these devices in their sites as ads to demonstrate that their items or administrations are either less expensive or superior to their rivals. Most PC specialist organizations, for example, Asseco Poland SA, Click Computers and Best - Buy utilize online client surveys and show those audits online as promoting instruments to pull in new clients. [19],[21],[23] The retailer can utilize this input to improve their exhibition and increment the consumer loyalty. Since a large number of the unsatisfied clients will give input to future clients, the retailer ought to guarantee most of their clients are fulfilled before distributing the criticism. Something else, this may construct a frightful notoriety for the organization.. [7],[ 9], ,11]

\section{DATA ANALYSIS AND INTERPRETATION}

Analysis of data is a process of inspecting,cleaning,transforming,andmodelingdatawiththeg oalofdiscovering

usefulinformation,suggesting conclusions,an dsupportingdecisionmaking.Dataanalysishasmultiple facts and approaches, encompassing diversetechniquesunderavarietyofnames, in differentbusiness,science, andsocialsciencedomains.

Revised Manuscript Received on July 22, 2019.

K.Poovarasan Student ,Department of MBA,Bharath institute of Higher Education \& Research,Tamilnadu, India, Email: poovarasank @gmail.com

Dr. Fabiyola Kavitha Associate Professor ,Department of MBA,Bharath institute of Higher Education \& Research,Tamilnadu, India, Email: fabiolakavitha@gmail.com

Dr.A.Kamal, Associate Professor ,Department of EEE,Bharath institute of Higher Education \& Research,Tamilnadu, India, Email: ak2_anvi@yahoo.co.in
Table 1:table showing ease of the installation software Table $\mathrm{N}_{0}$ : 1 Table showing ease of the installation of software

\begin{tabular}{|l|l|l|l|}
\hline SN & Particulars & Respondents & Percentage \\
\hline 1 & 1 (very dissatisfied ) & 5 & 1.17 \\
\hline 2 & 2 ( dissatisfied ) & 10 & 2.35 \\
\hline 3 & 3 (Neutral) & 0 & 0 \\
\hline 4 & 4 (Satisfied) & 350 & 82.35 \\
\hline 5 & 5 (very satisfied ) & 60 & 14.11 \\
\hline & Total & 425 & $100 \%$ \\
\hline
\end{tabular}

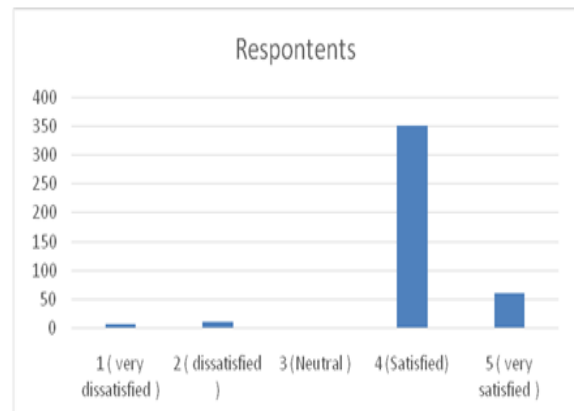

Fig 1: showing ease of the installation software

Table 2:showing completeness and accuracy of installation Table No: 2 Table showing completeness and accuracy of installation

\begin{tabular}{|l|l|l|l|}
\hline SN & Particulars & Respondents & Percentage \\
\hline & 1 (very dissatisfied ) & 6 & 1.41 \\
\hline & 2(dissatisfied) & 9 & 2.11 \\
\hline & 3 (Neutral) & 2 & 0.47 \\
\hline & 4 (Satisfied) & 400 & 94.11 \\
\hline & 5 (very satisfied) & 12 & 2.82 \\
\hline & & 425 & $100 \%$ \\
\hline
\end{tabular}

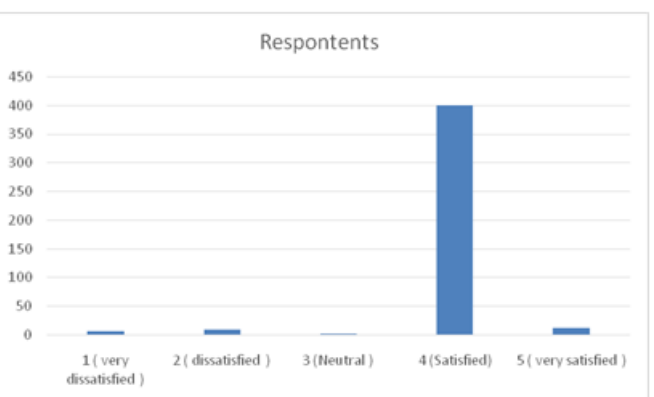

Fig 2: showing completeness and accuracy of installation

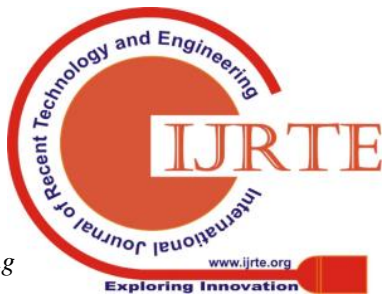




\section{Interpretation}

The above table indicates that $94.11 \%$ customers feel satisfied with the completeness and accuracy of software , $2.82 \%$ customers feel very satisfied, $2.11 \%$ customers are dissatisfied, while 1.41 customers feel very dissatisfied with completeness and accuracy of software[2 ],[4],[6]

\section{Table 3:people response}

\begin{tabular}{|l|l|l|l|}
\hline SN & Particulars & Respondents & Percentage \\
\hline & 1 (very dissatiffied) & 12 & 2.82 \\
\hline & 2 (dissatisfied) & 9 & 2.11 \\
\hline & 3 (Neutral) & 0 & 0 \\
\hline & 4 (Satisfied) & 375 & 88.23 \\
\hline & 5 (very satisfied) & 29 & 6.82 \\
\hline & & 425 & $100 \%$ \\
\hline
\end{tabular}

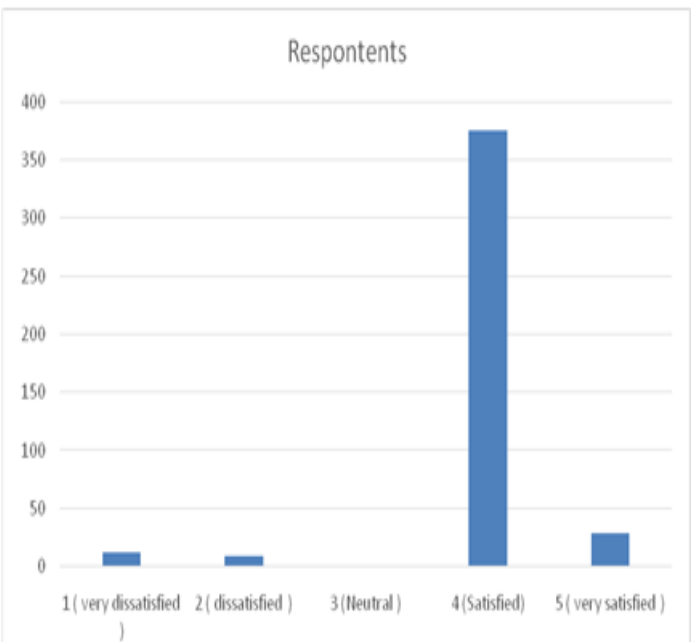

Fig 3:people response

TABLE 4:Peoples Respondents

\begin{tabular}{|l|l|l|l|}
\hline SN & Particulars & Respondents & Percentage \\
\hline & 1 (very dissatisfied ) & 13 & 3.05 \\
\hline & 2 (dissatisfied) & 2 & 0.47 \\
\hline & 3 (Neutral) & 0 & 0 \\
\hline & 4 (Satisfied) & 401 & 94.35 \\
\hline & 5 (very satisfied) & 9 & 2.11 \\
\hline & & 425 & $100 \%$ \\
\hline
\end{tabular}

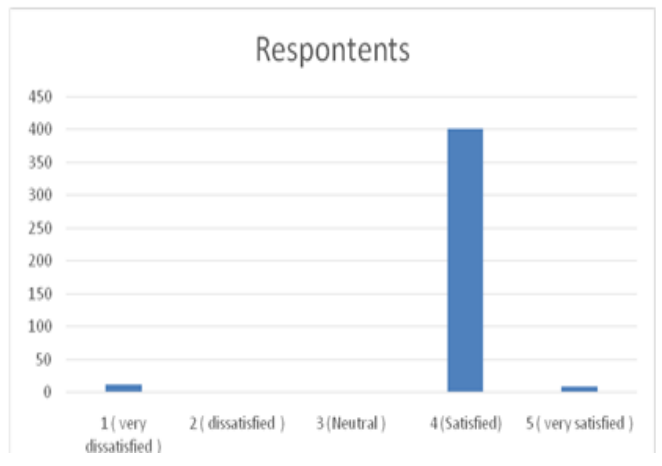

FIG 4: Peoples Respondents

table 5: showing long term ability of the software to function without errors and problems

\section{CHI-SQUARE}

\begin{tabular}{|l|l|l|l|}
\hline SN & Particulars & Respondents & Percentage \\
\hline & 1 (very dissatisfied ) & 0 & 0 \\
\hline & 2 (dissatisfied) & 0 & 0 \\
\hline & 3 (Neutral) & 10 & 2.35 \\
\hline & 4 (Satisfied) & 400 & 94.11 \\
\hline & 5 (very satisfied) & 15 & 3.52 \\
\hline & & 425 & $100 \%$ \\
\hline & & & \\
\hline
\end{tabular}

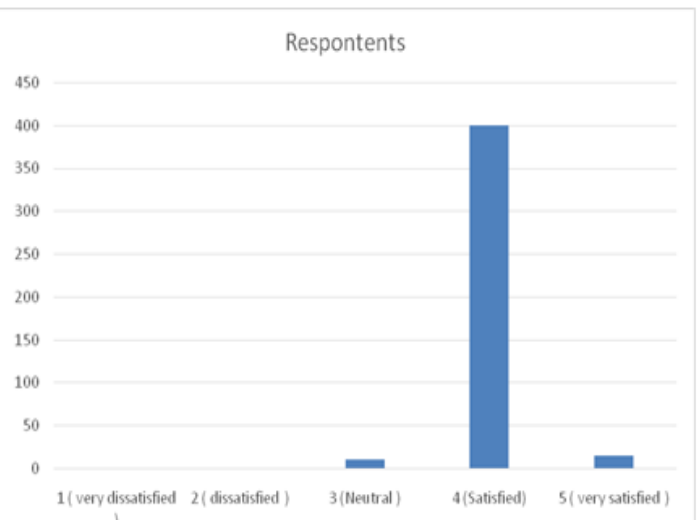

Fig 5: showing long term ability of the software to function without errors and problems

CHI-SQUARE

\section{Interpretation}

\section{1)Software to function without crash and service interruptions}

Solutions:- (i) Null hypos thesis:-Software does not have ability of the initially delivered software to function without crash and service interruptions [20],[22], [24]

(ii) Alternative hypothesis:- Software has ability of the initially delivered software to function without crash and service interruptions[8],[10],[12]

$\chi=\mathbf{E}[(\mathbf{0}-\mathbf{E})]=\mathbf{5 8 . 5 4 5}$

\section{$\mathbf{E}$}

Calculated value $=58.545$

\begin{tabular}{|c|c|c|c|c|}
\hline 0 & $\mathrm{E}=\frac{\text { R.TXC.T }}{\text { G.T }}$ & (O-E) & $(\mathrm{O}-\mathrm{E})^{2}$ & $\frac{(O-E)^{2}}{E}$ \\
\hline 12 & $21 \times 387 / 425=19.1$ & -7.1 & 50.41 & 2.63 \\
\hline 9 & $21 \times 38 / 425=1.87$ & 7.13 & 50.83 & 27.18 \\
\hline 375 & $404 \times 387 / 425=367.87$ & 7.13 & 50.83 & 0.135 \\
\hline 29 & $404 \mathrm{X} 38 / 425=0.025$ & 28.975 & 829.44 & 28.60 \\
\hline & Total & & & 58.545 \\
\hline
\end{tabular}


Degree of freedom :-

$$
\begin{aligned}
& \mathrm{V}=[\mathrm{r}-1][\mathrm{c}-1] \\
& \mathrm{V}=[2-1][2-1] \\
& \mathrm{V}=1 * 1=1
\end{aligned}
$$

Table value $=3.84($ constant $)$

Calculated value>Table value

It is not significant [25],[27],[29]

So alternative hypothesis is accepted. [13], [15] ,[17]

Conclusion:- Software has ability of the initially delivered software to function without crash and service interruptions.

2) Long term ability of the software to function without errors and

\section{6],[28],[30]problems}

\begin{tabular}{|l|l|l|}
\hline 2 & 2 & 4 \\
\hline 402 & 19 & 421 \\
\hline 404 & 21 & 425 \\
\hline
\end{tabular}

Solutions:-(1) Null hypos thesis:-

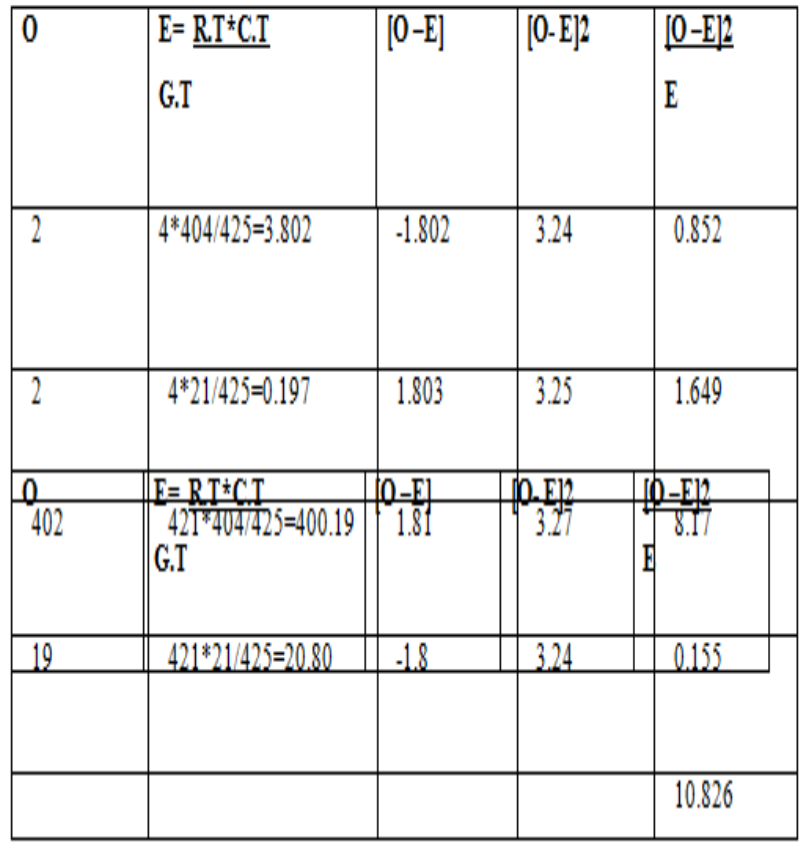

$\gamma=\mathrm{E}[(0-\mathrm{E})]=10.826$

E

$$
\chi=\frac{E[(0-E)]}{E}=10.826
$$

Calculated value $=10.826$

Degree of freedom :-

$$
\begin{aligned}
& \mathrm{V}=[\mathrm{r}-1][\mathrm{c}-1] \\
& \mathrm{V}=[2-1][2-1]
\end{aligned}
$$$$
\mathrm{V}=1 * 1=1
$$

Table value $=3.84$ (constant)

Calculated value $>$ Table value

It is not significant

So alternative hypothesis is accepted. [14],[ 16], [18]

Conclusion:-Software has long term ability of the software to function without errors and proble

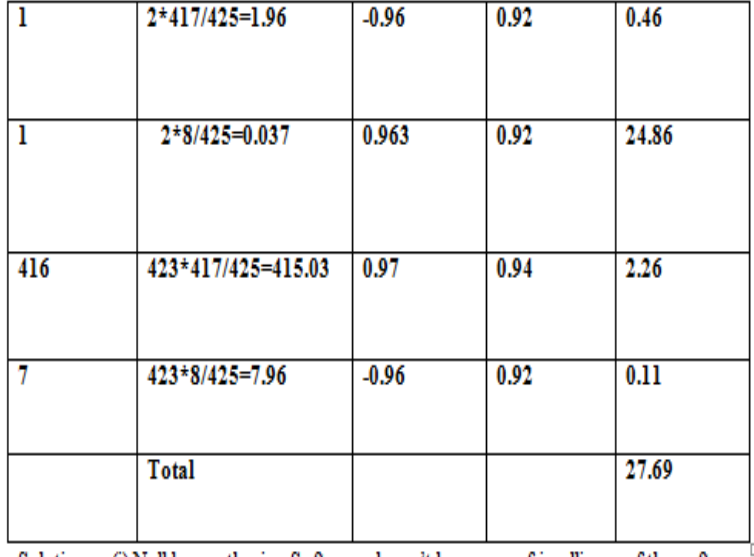

Solutions:- (i) Null hypos thesis:- Software doesn't have user friendliness of the software (ii) Altemative hypothesis:- Software has a user friendliness of the software $\chi=\mathrm{E}[(0-\mathrm{E})]=27,69$

E

Calculated value $=27.69$

Degree of freedom :-

$$
\begin{aligned}
& \mathrm{V}=[\mathrm{r}-1][\mathrm{c}-1] \\
& \mathrm{V}=[2-1][2-1] \\
& \mathrm{V}=1 * 1=1
\end{aligned}
$$

Table value $=3.84($ constant $)$

Calculated value $>$ Table value

It is not significant

So alternative hypothesis is accepted.

Conclusion:- Software has a user friendliness of the

\section{RESULTS}

$1.82 .35 \%$ of the customers feel satisfied ease of the installation of software.

2.94. $11 \%$ of the customers express satisfaction over the accuracy of the installation and appreciate the ability of software to function without crashes or service interruptions.

3.88.23\% of the customers feel satisfied with long term ability of the software to function without crashes or services interruptions.

4.93.64\% of the customers express satisfaction over the ability of the software to perform the tasks expected.

$5.97 .88 \%$ of the customers feel that soft ware is user friendly.

$6.71 .05 \%$ of the customers feel that software has the character of completeness, 
technical leadership compared to other similar products.

7. $70.82 \%$ of the customers feel that there is completeness of user documentation.

8. 82.35\% of the customers have expressed satisfaction over completeness of training.

9.88.23\% of the customers expressed satisfaction over usefulness of training.

10. $94.32 \%$ of the customers are satisfied with Boscosoftware product and service.

11. $70.58 \%$ of the customers expressed dissatisfaction over the non-availability of technical support

12. $47.5 \%$ of the customers feel that technical support is lacking in solving problems.

\section{SUGGESTIONS}

Since most of the customers expressed dissatisfaction over the technical support provided by the company to solve technical problems faced by the customers, it is suggested that The company shall create four regions and place the customers in any one of the regions based on the language and distance, need not be state wise. The company shall open branches in all the four regions and appoint branch manager in each of the region.Each branch shall have the technical support team, headed by the manager who keeps track of all issues faced by the customers and offers timely assistance to the customers.Each branch shall have technical support team, training team and marketing and finance team. The manager shall send the daily report to the head office.

2. As most of the customers expressed that completeness of the training is very important, it is suggested that The company shall prepare a training manual.The company shall ensure that trainings take place at a regular intervals. Training sessions could be class room model or off the class room model.Training module can be in different languages.

3. In order to increase the customer strength, it is suggested thatEach branch shall have marketing team which will continuously explore the market opportunities. The company shall set targets on weekly basis. There shall be customer care team in every branch which shall take care of existing customers.

4. In order to keep the money flow steady, following suggestions are made:Each branch shall have finance team which shall control the expenses and monitor the income.The team shall ensure that without nagging the customers payments from the customers are regular[1],[ 3],[5]

\section{CONCLUSION}

The PC programming item and administration industry division forcefully experiences client rot, yet numerous PC programming and administration organizations discover it is simpler to pull in new clients as opposed to keeping current clients, which is inverse to reality.
As the creator outlines in writing survey, showcasing studies have demonstrated that keeping current clients is four to multiple times simpler than pulling in new clients. In the event that this is valid, at that point for what reason do numerous PC administration organizations think the inverse? A tremendous measure of writing has been inspected and broad examination has been directed by the writer to address this fundamental inquiry. Since the majority of PC support item attributes are elusive, at that point the greater part of customary quality devices can't be utilized. Estimating the nature of conveyed administration and item furnishes the organization with the experiences to enchant and hold clients. By deciding clients' needs and satisfying them, the PC administration organizations hold fulfilled clients, yet in addition decrease the expense of accumulating new clients. In different words, fulfilling the client is viewed as essential for organization long haul achievement.

Numerous examinations demonstrate the purpose behind organizations' inability to continue consumer loyalty is an absence of a hearty model to gauge consumer loyalty level (Vivra, 1997). All in all, the items and administrations are heterogeneous, indivisible and elusive, which clarifies why various organizations think that its hard to gauge nature of the administration and accordingly, neglect to fulfill their client prerequisites

\section{REFERENCES}

1) BharthVajan R., Ramachandran S.,Psychographic dimensions of training,2016,International Journal of Pharmacy and Technology,V-8,I-4,P-23727-23729

2) Balakrishnan P., Bharthvajan R.,A study on human resource planning in hospitals in Chennai City,2014,International Journal of Applied Engineering Research,V-9,I-22,P-7503-7507

3) Priyadarsini P., Bharthvajan R.,Role of emotional intelligence training programme in reducing the stress of the nurses,2014,International Journal of Applied Engineering Research,V-9,I-22,P-7411-7421

4) Kerinab Beenu G., Bharthvajan R.,Empirical analysis on the cosmetic buying behavior of young women in South India,2014,International Journal of Applied Engineering Research,V-9,I-22,P-7361-7366

5) Balakrishnan P., Bharthvajan R.,Whistling in the wind,2014,International Journal of Applied Engineering Research,V-9,I-22,P-7586-7593

6) Krishnan B., Peter M.,Health hazards of Indian Bpo employee-an alarming issue,2014,International Journal of Applied Engineering Research,V-9,I-22,P-7336-7341

7) Kerinab Beenu G.H., Peter M.,Role of insurance in economic development,2014,International Journal of Applied Engineering Research,V-9,I-22,P-7532-7539

8) Balakrishnan P., Peter M., Priyadarsini P.,Efficiency of safety measures for wellbeing of employees in manufacturing industry,2014,International Journal of Applied Engineering Research,V-9,I-22,P-7376-7382

9) Anbarasi M., Praveen Kumar S.,Online sales promotions of herbal products and its effectiveness towards tanisha.com,2019,Indian Journal of Public Health Research and Development,V-10,I-1,P-195-200

10) Anbarasi M., Praveen Kumar S.,Various online marketing and promotions strategies to improve the validation towards the organic products in the pharmaceutical sectors,2019,Indian Journal of Public Health Research and Development,V-10,I-1,P-263-269

11) Loganathan R., Praveen Kumar S.,Grievance handling a key factor for solving issues of employees in an organization,2014,International Journal of Applied Engineering Research,V-9,I-22,P-7483-7491

12) Loganathan R., Praveen Kumar S.,Study on preference of private label brands in super and Hypermarkets,2014,International Journal of Applied Engineering Research,V-9,I-22,P-7327-7335

13) Smitha M., Praveen Kumar S.,Understanding stress and its managementamong the nurses in Chennai city,2014,International Journal of Applied Engineering Research,V-9,I-22,P-7560-7565 
14) Kerinab Beenu G.H., Praveen Kumar S.,A study on the investment behavior of Chennai investors in mutual fund schemes,2014,International Journal of Applied Engineering Research,V-9,I-22,P-7520-7525

15) Loganathan R., Praveen Kumar S.,Retention strategies key for organizational productivity,2014,International Journal of Applied Engineering Research,V-9,I-22,P-7443-7447

16) Pavithra J., Ganesan M., Brindha G.,State wise analysis of microfinance sector in India,2016,International Journal of Pharmacy and Technology,V-8,I-4,P-23417-23432

17) Pavithra J., Ganesan M.,A comparative study on microfinance in India and abroad,2016,International Journal of Applied Business and Economic Research,V-14,I-8,P-5471-5476

18) Pavithra J., Ganesan M.,A study on awareness and impact of micro-financial schemes,2016,International Journal of Applied Business and Economic Research,V-14,I-8,P-5449-5460

19) Senthilmurugan P., Pavithra J.,Consumer preference towards organised retailing with reference to Big Bazaar,2014,International Journal of Applied Engineering Research,V-9,I-22,P-7469-7475

20) Senthilmurugan P., Pavithra J.,Implication of social media marketing in growing healthcare industry,2014,International Journal of Applied Engineering Research,V-9,I-22,P-7448-7456

21) Loganathan R., Pavithra J.,Consumer perception towards private label brand over other brands in super markets and hypermarkets,2014,International Journal of Applied Engineering Research,V-9,I-22,P-7355-7360

22) Kerinab Beenu G., Pavithra J.,Tradeâ€"off between liquidity and profitability in logistics industry,2014,International Journal of Applied Engineering Research,V-9,I-22,P-7398-7401

23) Kerinab Beenu G., Pavithra J.,A study on the prospective consumerâ€ $€^{\mathrm{TM}_{S}}$ perception towards utility cars in Chennai city,2014,International Journal of Applied Engineering Research,V-9,I-22,P-7526-7531

24) Pavithra J., Dilli Babu P., Ambuli T.V.,A study on budgetary control at Maruti Service Masters, Chennai,2014,International Journal of Applied Business and Economic Research,V-12,I-2,P-151-161

25) Pavithra J., Dilli Babu P., Ambuli T.V.,A study on customer satisfaction of retro Garments Pvt Ltd, Chennai,2014,International Journal of Applied Business and Economic Research,V-12,I-2,P-381-391

26) Kerinab Beenu G.H., Pavithra J., Senthilmurugan P.,A study on the influence of promotional activities for TATA ARIA among consumers in Chennai,2014,International Journal of Applied Engineering Research,V-9,I-22,P-7572-7578

27) Vijayaragavan S.P.,An investigative expert that's general FBG sensors,International Journal of Mechanical Engineering and Technology,V-8,I-8,PP-1500-1505,Y-2017

28) Vijayaragavan S.P.,Equalization routing protocol for Wi-Fi sensor strategy,International Journal of Mechanical Engineering and Technology,V-8,I-8,PP-1662-1666,Y-2017

29) Karthik B., Kiran Kumar T.V.U., Vijayaragavan P., Bharath Kumaran E.,Design of a digital PLL using 0.35 $\hat{\mathrm{I}}^{1 / 4 \mathrm{~m}}$ CMOS technology,Middle East Journal of Scientific Research,V-18,I-12,PP-1803-1806,Y-2013

30) Kanniga E., Selvaramarathnam K., Sundararajan M.,Kandigital bike operating system,Middle - East Journal of Scientific Research,V

31) Jasmin M., Vigneshwaran T., Beulah Hemalatha S.,Design of power aware on chip embedded memory based FSM encoding in FPGA,International Journal of Applied Engineering Research,V-10,I-2,PP-4487-4496,Y-2015

32) Jasmin M.,Optimization techniques for low power VLSI circuits,Middle East Journal of Scientific Research,V-20,I-9,PP-1082-1087,Y-2014

33) Jasmin M., Vigneswaran T.,Fuzzy controller for error control of on - Chip communication,2017 International Conference on Algorithms, Methodology, Models and Applications in Emerging Technologies, ICAMMAET 2017,V-2017-January,I-,PP-1-5,Y-2017

\section{AUTHORS PROFILE}

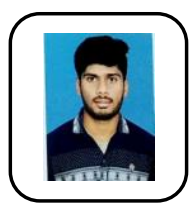

K.Poovarasan Student ,Department of MBA,Bharath institute of Higher Education \& Research,Tamilnadu, India,

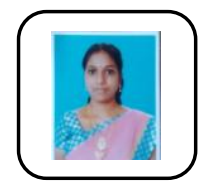

Fabiola Kavitha Associate Professor ,Department of MBA,Bharath institute of Higher Education \& Research, Tamilnadu, India, Email: fabiolakavitha@gmail.com

Dr.A.Kamal, Associate Professor ,Department of EEE,Bharath institute of Higher Education \& Research,Tamilnadu, India 